REFERENCES

FARTHING, G. W., \& HEARS $\dot{T}$, E. Generalization gradients of inhibition after different amounts of training. Joumal of the Experimental Analysis of Behavior, 1968, 11, 743-752.

HONIG, W. K., BONEAU, C. A. BURNSTEIN, K. R., \& PENNYPACKER, H. S. Positive and negative generalization gradients obtained after equivalent training conditions. Journal of Comparative \& Physiological Psychalogy, 1963, 56, 111-116.

JENKINS, H. M. Generalization gradients and the concept of inhibition. In $D$ Mostofsky (Ed.), Stimulus generalization. Palo Alto: Stanford University Press 1965. Pp. 55-61.

JENKINS, H. M.. \& HARRISON, R. H.
Generalization gradients of inhibition following auditory discrimination learning. Journal of the Experimental Analysis of Behavior, 1962, 5, 435-441.

PETERSON, N. Effect of monochromatic rearing on the control of responding by wavelength. Science, $1962,136,774-775$.

ROSEN, A. Determinants of inhibition: The effect of massed extinction, behavioral contrast, and reinforcement. Unpublished doctoral dissertation, Columbia University, 1970 .

SELEKMAN, W. Preference gradients and post discrimination gradients along the wavelength continuum after training to white light. Unpublished doctora dissertation, Columbia University, 1970.

\title{
A sex difference in the extinction of avoidance behavior in rats
}

\author{
WILLIAM W. BEATTY and PATRICIA ANN BEATTY \\ North Dakota State University, Fargo, N. Dak. 58102 \\ and \\ ROBERT E. BOWMAN \\ University of Wisconsin, Madison, Wis. 53706
}

Significantly more females than males met criterion for the acquisition of a shuttle-avoidance response. Among $S$ s meeting criterion, females displayed increased resistance to extinction of the avoidance response. The relationship between sex differences in avoidance behavior and adrenocortical functioning was discussed.

Recently, Beatty \& Beatty (1970) demonstrated that female rats acquire a two-way active avoidance response more rapidly than males over a wide range of US intensities. Manipulations which increase circulating levels of ACTH also enhance the acquisition of avoidance behavior by males at high US intensities (Beatty, Beatty, Bowman, \& Gilchrist, 1970), and ACTH is known to play an important role in the maintenance of avoidance responding during extinction tests (de Wied, 1966; Murphy \& Miller, 1955). Female rats have larger anterior pituitary and adrenal glands (Swanson \& van der Werff ten Bosch, 1963) and higher blood corticosterone levels

(Ader, 1968; Kitay, 1961), suggesting that their ACTH levels are also higher. If this hypothesis is correct, then females would be expected to be more resistant to the extinction of an active avoidance response. The present experiment tested this hypothesis and examined the relationship of acquisition and extinction performance to resting plasma corticosterone levels in both sexes. SUBJECTS

Thirty-six rats of the Holtzman strain, 18 of each sex, served as Ss. Males weighed $420-560 \mathrm{~g}$; females weighed $310-440 \mathrm{~g}$. All Ss had prior breeding experience. Other work (Beatty \& Beatty, 1970) indicates that, in adult rats of this strain, age, weight, and reproductive experience do not affect avoidance acquisition. The Ss were caged singly in a room with continuous illumination and were fed Wayne Lab Blox and water ad lib. One female $\mathbf{S}$ was pregnant and was dropped from the experiment.

\section{PROCEDURE}

Acquisition and extinction tests were conducted in two identical shuttleboxes that have been described elsewhere (Schwartzbaum, Green, Beatty, \& Thompson, 1967). Each acquisition or extinction session consisted of a 5-min period, during which $S$ could shuttle freely from one side of the lighted shuttlebox to the other, followed by 25 test trials presented on a 60-sec FI schedule. During acquisition, the CS (offset of light in the compartment occupied by S) preceded the onset of the US by $10 \mathrm{sec}$ and was terminated by a shuttling avoidance response. Otherwise, the CS overlapped the US, and both were terminated by an escape response. No adaptation tests were run because previous work (Beatty \& Beatty, 1970) indicated that rats of this strain do not escape the offset of light under the present conditions. US intensity was $1.0 \mathrm{~mA}$.

Acquisition began on the first experimental session and continued until $S$ met a criterion of at least 20 avoidance responses out of 25 trials for two consecutive sessions or until $S$ received 200 training trials. Extinction tests began the day after $S$ met the acquisition criterion and continued for three consecutive sessions (75 trials). During extinction, the CS remained on for $10 \mathrm{sec}$ unless terminated by a shuttling response. If $S$ failed to shuttle during the 10 -sec CS period, the CS terminated automatically and the ITI began. Other parameters were the same as in acquisition.

Several days after the end of extinction tests, all Ss were sacrificed under ether anesthesia. Blood was withdrawn from the right ventricle, centrifuged, and the plasma frozen for corticosterone assay by the protein-binding method (Murphy, 1967). Data on this measure were lost for one female that met acquisition criterion.

\section{RESÚLTS}

Performance during acquisition is shown in Table 1. Fewer than $30 \%$ of males, but greater than $80 \%$ of females, met the acquisition criterion $\left(x^{2}=8.41, \quad \mathrm{df}=1, \quad \mathrm{p}<.01\right)$. Nevertheless, the performance of male and female $S$ s that did meet criterion was quite similar. There were no significant differences between these groups in the number of escape or avoidance responses to criterion or in the number of avoidance responses 
Table 1

Mean Performance During Acquisition*

\begin{tabular}{|c|c|c|c|c|c|c|}
\hline & & $\mathbf{N}$ & $\begin{array}{l}\text { Escapes to } \\
\text { Criterion }\end{array}$ & $\begin{array}{l}\text { Avoidances } \\
\text { to Criterion }\end{array}$ & $\begin{array}{c}\text { Avoidance Responses } \\
\text { Last Training } \\
\text { Session }\end{array}$ & $\begin{array}{l}\text { Mean Plasma } \\
\text { Corticoste- } \\
\text { rone }\left(\mu_{\mathrm{g}} \%\right)\end{array}$ \\
\hline Males & $\begin{array}{l}\text { Met Criterion } \\
\text { Failed }\end{array}$ & $\begin{array}{r}5 \\
13\end{array}$ & $19.2 \pm 7.6$ & $\begin{array}{c}55.8 \pm 7.6 \\
-\end{array}$ & $22.6 \pm 1.2$ & $\begin{array}{r}9.7 \pm 1.2 \\
20.7 \pm 11.3\end{array}$ \\
\hline Females & $\begin{array}{l}\text { Met Criterion } \\
\text { Failed }\end{array}$ & $\begin{array}{r}14 \\
3\end{array}$ & $25.7 \pm 18.4$ & $54.6 \pm 8.9$ & $23.6 \pm 1.3$ & $\begin{array}{l}43.4 \pm 27.0 \\
36.2 \pm 19.0\end{array}$ \\
\hline
\end{tabular}

$* \mathbf{S D}$

made on the last training session (all $p>.10)$.

Analysis of the plasma corticosterone data revealed a significant overall sex difference $(\mathrm{F}=8.62, \quad \mathrm{df}=1 / 30, \quad \mathrm{p}<.01, \quad$ by unweighted means analysis of variance, data from all male Ss). Males that met the acquisition criterion had lower resting corticosterone levels than males that failed to meet criterion $(t=3.31$, $\mathrm{df}=16, p<.01$ ), but there was no significant difference between female "learners" and "nonlearners."

As seen in Fig. 1, there was a marked sex difference in performance during extinction tests. Females made significantly more responses to the CS throughout these tests $(F=4.63$, $\mathrm{df}=1 / 17, \mathrm{p}<.05$ ). Although plasma corticosterone levels were positively correlated with the number of responses to the $C S$ throughout extinction (Pearson $r=.28$ ) and on the comparing data from all female Ss to

first extinction session $(r=.33)$ neither of these trends attained statistical significance. The sex difference in resistance to extinction was not paralleled by reliable difference in shuttling activity, either in the periods preceding extinction tests or during the intertrial intervals. DISCUSSION

Female rats surpassed males in the acquisition of active avoidance behavior and had higher plasma corticosterone levels, replicating earlier findings (Ader, 1968; Beatty \& Beatty, 1970; Kitay, 1961). As predicted from the assumption that females have higher ACTH levels, they were more resistant to the extinction of the avoidance response. Although the data clearly demonstrated that the greater resistance to extinction displayed by female Ss did not arise from higher asymptotic levels of performance at the start of extinction, the failure to find substantial positive correlations

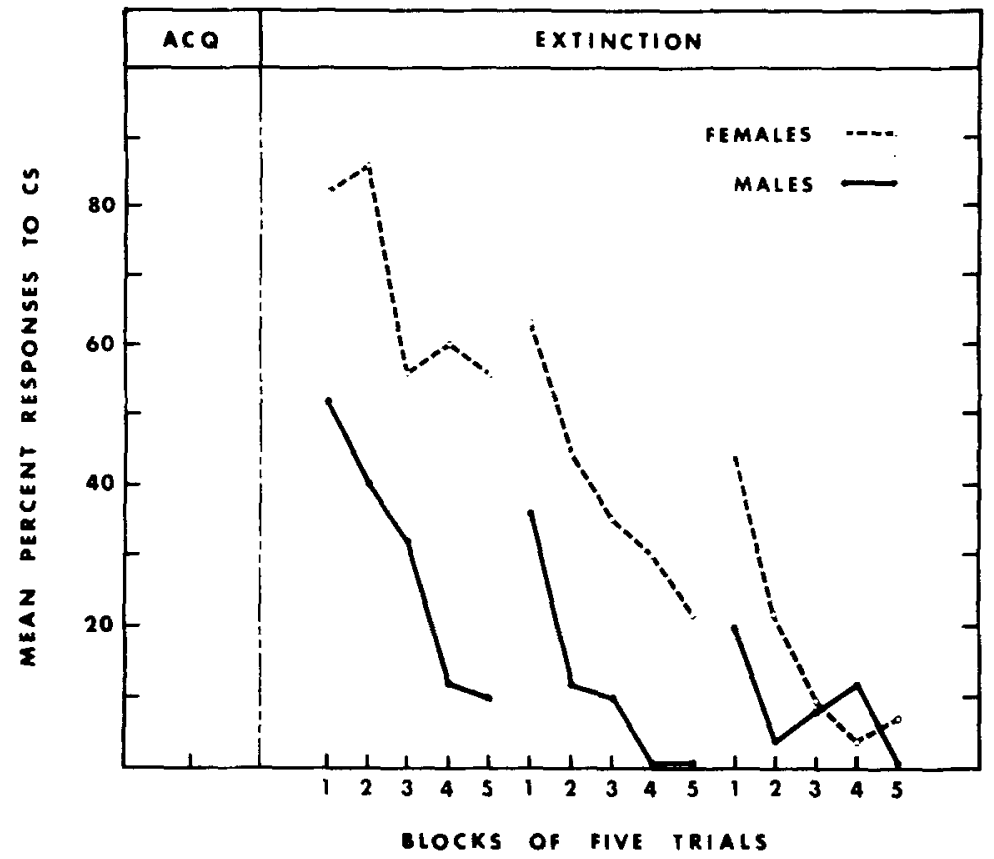

SESSIONS

Fig. 1. Mean percentage responses to the CS during the last block of five acquisition trials and during blocks of five trials throughout extinction. between plasma corticosterone levels and performance during extinction does not support the hypothesis that higher ACTH levels are responsible for the greater resistance to extinction of females. This failure may not be crucial, however, since other work indicates that performance on shock-motivated tasks is more likely to relate to levels of corticosterone induced by stress than to resting levels (e.g., Wertheim, Conner, \& Levine, 1969).

\section{REFERENCES}

ADER, R. Effects of early experiences on emotional and physiological reactivity in the rat. Journal of Comparative \& Physiological Psychology, 1968, 66, 264-268.

BEATTY, P. A., BEATTY, W. W. BOWMAN, R. E., \& GILCHRIST, J. C. The effects of ACTH, adrenalectomy and dexamethasone on the acquisition of an avoidance response in rats. Physiology \& Behavior, 1970, 5, 939-944.

BEATTY, W. W., \& BEATTY, P. A. Hormonal determinants of sex differences in avoidance behavior and reactivity to electric shock in the rat. Journal of Comparative \& Physiological Psychology. $1970,73,446-455$.

KITAY, J. I. Sex differences in adrenal cortical secretion in the rat. Endocrinology, 1961, 68,818-824.

MURPHY, B. E. P. Some studies of the protein-binding of steroids and their application to the routine micro and ultra micro measurement of various steriods in body fluids by competitive protein-binding radioassay. Journal of Clinical Endocrinology \& Metabolism, $1967,27,973-990$.

MURPHY J V \& MILLER, R. E. The effect of adrenocorticotrophic hormone (ACTH) on avoidance conditioning in the rat. Journal of Comparative \& Physiological Psychology, 1955, 48, 47-49.

SCHWARTZBAUM, J. S., GREEN, R. H. BEATTY, W. W., \& THOMPSON, J. B. Acquisition of avoidance behavior following septal lesions in the rat. Journal of Comparative \& Physiological Psychology, 1967, 63, 95-104.

SWANSON $\mathrm{H}, \mathrm{H}$ \& van der WERFF ten BOSCH, J.J. Sex differences in growth of rats and their modification by a single injection of testosterone propionate shortly after birth. Journal of Endocrinology, 1963, 26, 197-207.

WERTHEIM, G. A., CONNER, R. L., \& LEVINE, S. Avoidance conditioning and adrenocortical function in the rat. Physiology \& Behavior, 1969, 4, 41-44. de WEID, D. Inhibitory effect of ACTH and related peptides on extinction of conditioned avoidance behavior in rats. Proceedings of the Society for Experimental Biology \& Medicine, 1966, 122, 28-32. 